\title{
Church's Response to the Ecological Crisis in a Small Country - the Case of the Roman Catholic Church in Latvia
}

\author{
Weronika Felcis ${ }^{1 *}$, Elgars Felcis ${ }^{2}$ \\ ${ }^{1}$ Centre for Evaluation and Public Policy Analysis, Jagiellonian University \\ ${ }^{2}$ Institute of Advanced Social and Political Research, Faculty of Social Sciences, University of Latvia \\ *weronika.felcis@gmail.com•0RCID 0000-0003-3301-7303
}

\section{Summary}

Due to historical and contextual factors explained in this article, the Latvian Roman Catholic Church currently does not play any significant role in environmental protection or ecological crisis awareness building in the country. However, being called by Pope Francis in his encyclical Laudato si', recently more of the reflection was given to the call for ecological conversion. Considering Church resources based on publicly available data, the authors describe the limitations and opportunities to strengthen the Church current response to the ecological crisis.

\section{Keywords}

ecological conversion, Latvia, environmental crisis, Christianity, Catholic Church

\section{Historical position of the Roman Catholic Church in Latvia}

The Latvian Roman Catholic Church has substantially different position in society than the Church in Poland. During the struggle for independence in the beginning of the 1990s, it was predominantly civic and environmental organizations and their successful campaigns, not the Catholic Church who were providing more sense of unity and success in civil disobedience actions. The weakened role of the Catholic, Lutheran and Protestant Churches in Latvia was because of the Soviet Union systemic attempts to uproot institutional activity of people in Christian churches.
The active participation and celebration of Christian holidays was prosecuted in the country. After almost 50 years of systemic secularization of the country the religiosity rates across Latvia and other Baltic Countries have dropped dramatically. Similarly, as other countries with post-Soviet legacy, Latvia is a country where people were prosecuted for any disobedience towards the state system, many people have perished in the WWI, WWII and deportations to Siberia. The current social and environmental activism of the Church must be then assessed while taking into account these two factors. 


\section{Civil society activism, climate change awareness and relation to nature in Latvia}

In spite of the scientific consensus on climate change (IPCC, 2014; IPCC, 2018), only $30 \%$ of Latvians consider climate change to be one of the main environmental problems in Latvia. Differences on this issue can be identified in some sociodemographic groups. Regional differences on this issue are essential. Only 25\% of the Riga inhabitants consider climate change as an environmental problem as opposed to $37 \%$ of respondents living in regions of Latvia (outside Riga metropolitan area) and even $39 \%$ of those surveyed in places with less than 5,00o inhabitants. There are minor differences in employment status-from all the major environmental problems in Latvia, the working population mentions climate change more often (34\% of public sector employees and $33 \%$ of private sector workers) compared to the unemployed (25\% of those who do not work consider climate change as one of the main environmental problems ${ }^{1}$. There are no statistically significant differences between people of different ages and levels of education.

$27 \%$ of the Latvian population think that they are personally affected by climate change (the question: „Which of these environmental problems affect you and your family?"). Climate change is considered to be one of the main environmental problems in Latvia because it affects people personally (statistically significant relationship). In addition, large families with children (33\% in 4 people household, $32 \%$ with children under 18 ), as well as the public sector workers (36\%) and respondents living in places with less than 10,000 inhabitants (35\%) believe that they are personally affected by climate change (SUSTINNO, 2017).

Therefore it can be concluded that unlike in some other studies, which emphasize the link between higher education and higher

1 All these differences are statistically significant. environmental awareness among large cities (Xiao \& Dunlap, 2007; Xiao, Dunlap, \& Hong, 2012), in Latvia more people in the regions believe that climate change is a major problem and influences them personally. These responses indicate that the urban environment contributes to the alienation of people from the biosphere and its processes - the obvious consequences of climate change are relatively less visible in Riga than in rural areas where they are already beginning to affect agriculture, for example, the summer 2017 floods in the vicinity of Rezekne and the droughts of the 2018 summer with dramatic consequences for farmers and crop loss.

At the same time, respondents who have pointed out that climate change is one of the main environmental problems in Latvia, more often agree with the statement that "people are too worried that human progress is damaging to the environment" (SUSTINNO 2017). So it can be concluded that while some people are concerned about the environmental situation and they are aware that climate change is a major problem, they-in the spirit of "ecological modernization"-believe that the existing economic system will be able to solve the problems that the system itself has to large extent caused.

\section{Recent response of the Latvian Catholic Church to the call of Pope Francis ${ }^{2}$}

At the global scale, issues of environmental destruction have impacted not only the societies of the 'Global South', but all humanity around the globe. Therefore, not only politicians speak about the issue, but also religious leaders. Pope Francis voices the connection between the cry of the Earth and the cry of the poor (the fundamental

2 Sadly enough, even though we contacted several researchers and official Information Centre of Catholic Church in Latvia in request for the data, we received only the basic statistical data without much of the description. Therefore further part of this article will be based on our best knowledge and understanding of Catholic Church in Latvia. 
thesis of an integral ecology proposed by the Catholic Church). Nonetheless, social and environmental problems are very rarely connected in Latvian public discourse. One of the rare examples of following integral ecology principle in Latvia is Caritas - an international organization has in its statute care for poor and promotion of responsible lifestyles with respect to Creation ${ }^{3}$. Therefore, in May 2018 Caritas in Latvia invited Fr. Stanislaw Jaromi, head of St. Francis' of Assisi Environmental Movement in Poland to present a closer view of the historical roots, importance and potential of integral ecology. The outputs of the project were:

- a lecture for all Catholic priesthood in Latvia;

- a lecture for the youth from the Catholic high school in Riga;

- an ecumenical meeting with parishioners on how to implement Laudato si'

- a radio interview on integral ecology;

- a visit to one of the regional churches and preaching Laudato si' spirituality;

- an attempt to create an Ecumenical Taskforce on Environmental Protection;

- a written report with possible resolutions for Latvian Catholics.

The project resulted in discussions how Riga could become a carbon neutral diocese to which the Church leadership was very open. Until now, energy audits were made for the vast majority of the Church buildings in the Riga diocese and many isolation improvements projects have been implemented thanks to foreign funds and state support in some cases. However, since there are no concrete solutions found for alternative energy sources for the buildings in the possession of the Catholic Church, the idea of diocese carbon neutralization was not developed onwards.

3 In Latvian further explanation of this point show the importance of individual ecological transition in economic use of resources such as water, electricity, recycling.
These topics also appear in some media. In the Catholic Radio - Radio Maria - appeared 24 episode series of radio programs analysing Laudato si' by the radio director. There are also three regular programs on ecology and Christianity and some singular discussions on anniversary of Laudato si'. Many articles have appeared in the Catholic Messenger - the main Catholic Church magazine. Finally, a conference organized in the Faculty of Social Sciences of Latvian University last year - before Pope visit in the Baltic States in main Library of University - included discussions about relevance of the Pope Francis teaching for Latvian society (Web-o1).

\section{Analysis of the Church potential in the of its resources}

The data available from Information Centre of Catholic Church in Latvia shows the basic statistics of human resources available in Latvia - a country of $64,589 \mathrm{~km}^{2}$ and population of app. 1,920,000 people.

As we can observe, most of the clergy is available in the central diocese with the capital as well as Eastern part, traditionally the more Catholic part of the country (Rezekne-Aglona). Nonetheless, the majority of the priests are serving more than one parish. Parishes are often quite distant from each other. Especially outside of the Riga region the population density is low and to effectively commute between church members or parishes, priests must have cars available.

Church buildings are big, and its energy efficiency is being improved by insulation projects from year to year. Nonetheless, none of the renewable energy ways is an easy solution for heating systems or for using electricity. There are no available subsidies or extra funding available for energy transitions in Latvia, especially for religious institutions.

Secondly, the Latvian Catholic Church is still very structured and hierarchical. Even despite that women are often an active part of the community, rarely any of their task is 
Table 1. Clergy resources and parishes in Catholic Church in Latvia ${ }^{4}$

\begin{tabular}{lccccc}
\hline & Riga Diocese & Rezekne-Aglona Diocese & Jelgava Diocese & Liepaja Diocese \\
\hline Bishops & 4 & 1 & 2 & 2 \\
\hline Priests & 58 & 64 & 25 & 16 \\
\hline Deacons & 3 & 3 & 0 & 0 \\
\hline Parishes & 77 & 117 & 63 & 32 \\
\hline
\end{tabular}

left for their full responsibility, including the decision making. It means that every task in the parish is supervised or managed by the priest. That, in turn, in majority of the cases, limits activism of parishioners.

Socially, the church community is also not a central connector to the social fabric and therefore except spiritual and religious holidays people rarely connect to each other, without much involvement in other life spheres. Therefore, the topic of ecology and care for Creation is seldomly appearing in speeches or writings of clergy, and even less often in the actions of parishioners. That is also the reason why there are no linkages between the Church and other organizations with an environmental or social focus.

\section{Opportunities}

Even despite all the presented limitations, some important actions can be undertaken to limit greenhouse emissions and respond more fully to Laudato si' call for transformations. On one hand, clergy and local consecrated communities statistically will not change much the carbon neutrality of the country. On the other hand, the power of their action lies not only in leading by example, but in inspiring people to make changes in their lifestyles and prepare them for climate change effects which requires peaceful deep adaptation already now. This can be done, for example, by changing the food habits and sourcingpromoting limiting meat diet and providing products from organic farms (through the

4 In addition to this, in Latvia exist 6 consecrated persons orders, 12 congregations and 4 secular institutes. direct shopping from a farmers' network). Any renovations of the buildings should primarily consider ecological alternatives for the materials and, if possible, rain and grey water systems management should be created for parish buildings (to show respect to scarcity of water which can become a problem in Latvia). This could be subsequently used for parish common gardens and care for native wildlife locally. Yet the obvious easy first step is to start with limiting waste (increasing waste problem awareness, leading by example during events organization, recycling exemplary) and creating materials and sermons, preparing and promoting integral ecology rules and organizing Creation Care events. Above all, the problems of the environment should be treated by the Catholic Church in Latvia much more seriously and responding to the call of the Pope Francis to actively participate in transforming our throw-away culture (Francis 2015: No. 217).

\section{Bibliography}

Crutzen P. J., 2002, Geology of mankind, Nature, vol. 415, 23.

Fazey et.al., 2018, Ten essentials for actionoriented and second order energy transitions, transformations and climate change research, Energy Research \& Social Science, vol. 40, 54-70. Fletcher, R. \& C. Rammelt, 2016, Decoupling: A Key Fantasy of the Post-2015 Sustainable Development Agenda, Globalizations, vol. 14(3), 450-467.

Folke C., 2006, Resilience: The emergence of a perspective for social-ecological systems analyses, Global Environmental Change, vol. 16(3), 253-267.

Francis, 2015, Encyclical letter (to si', (Rome, 24.05.2015) <w2.vatican.va/content/francesco/ en/encyclicals/documents/papa-francesco 
_20150524_enciclica-laudato-si.html>, accessed: 17.06.2019.

IPCC, 2014, Climate Change 2014. Synthesis Report. Summary for Policymakers. Contribution of Working Groups I, II and III to the Fifth Assessment Report of the Intergovernmental Panel on Climate Change [Core Writing Team, R.K. Pachauri and L.A. Meyer (eds.)]. IPCC, Geneva, Switzerland. Available online: $<w w w . i p c c . c h / p d f / a s s e s s m e n t-$ report/ar5/syr/AR5_SYR_FINAL_SPM.pdf $>$, accessed: 08.06.2019.

IPCC, 2018, Global Warming of 1.5 degrees. Available online: <www.ipcc.ch/report/sr15/>, accessed: 8.06.2019.

ISSP Research Group, 2003, International Social Survey Programme: Environment II - ISSP 2000. GESIS Data Archive, Cologne. ZA3440 Data file Version 1.0.0, doi:10.4232/1.3440

ISSP Research Group, 2012, International Social Survey Programme: Environment III - ISSP 2010. GESIS Data Archive, Cologne. ZA5500 Data file Version 2.0.0, doi:10.4232/1.11418

Steffen W., Broadgate W., Deutsch L., Gaffney O. and Ludwig C., 2015b, The trajectory of the Anthropocene: The Great Acceleration, Anthropocene Review, vol. 2(1), 81-98.
Steffen W., Richardson K., Rockström J., Cornell S.E., Fetzer I., Bennett E.M., Biggs R., Carpenter S.R., de Vries W., de Wit C.A., Folke C., Gerten D., Heinke J., Mace G.M., Persson L.M., Ramanathan V., Reyers B. and Sörlin S., 2015a, Planetary boundaries: Guiding human development on a changing planet, Science, vol. 347(6223).

SUSTINNO, 2017, Sociological survey in the project "Latvijas pēckrīzes procesi globālā kontekstā SUSTINNO" (Latvian post-crisis processes in the global context, SUSTINNO), December 2017. Market and social research centre "Latvijas Fakti". Xiao C., Dunlap R., 2007, Validating a Comprehensive Model of Environmental Concern Cross-Nationally: A U.S.-Canadian Comparison, Social Science Quarterly, vol. 88(2), 471-493.

Xiao C., Dunlap R.E., Hong D., 2012, The Nature and Bases of Environmental Concern among Chinese Citizens, Social Science Quarterly, vol. 94(3), 672-690.

(Web-01) Cieślak T., 2018, Łotwa: o Papieżu $i$ ekologii (Latvia: on the Pope and Ecology), $<$ www.vaticannews.va/pl/kosciol/news/2018-06/ lotwa-papiez-franciszek-ekologia-podroz.html>, accessed: 8.08.2019.

\section{Odpowiedź Kościoła na kryzys ekologiczny w małym państwie. Przypadek Kościoła katolickiego na kotwie}

\section{Streszczenie}

Czynniki historyczne i kontekstowe zaprezentowane w tym artykule potwierdzają, że Kościół rzymskokatolicki na Łotwie nie odgrywa znaczącej roli w ochronie środowiska ani w budowaniu świadomości ekologicznej w tym kraju. Jednak wezwany przez papieża Franciszka w encyklice Laudato si', poświęca obecnie więcej refleksji kwestii nawrócenia ekologicznego. Biorąc pod uwagę publicznie dostępne dane na temat zasobów Kościoła katolickiego na Łotwie, autorzy opisują ograniczenia i możliwości wzmocnienia reakcji Kościoła na kryzys ekologiczny.

\section{Słowa kluczowe}

ekologiczne nawrócenie, Łotwa, kryzys środowiskowy, chrześcijaństwo, Kościół katolicki 


\section{Noty autorskie}

ELGARS FELCIS - badacz na Uniwersytecie Łotewskim i aktywista środowiskowy na Łotwie. W 2017r. założył Otwarte Gospodarstwo "Zadini, jest prezesem Łotewskiego Stowarzyszenia Permakultury. Zainteresowany głęboką adaptacją, transfomacją energetyczną i tworzeniem wspólnot intencjonalnych.

WeroniKa FelCIS - socjolożka, ewaluatorka i aktywistka. Sekretarz w Komisji Nadzorczej Międzynarodowej Organizacji na rzecz Współpracy w Ewaluacji. Odkąd zamieszkała na Łotwie w 2016 współpracuje z organizacjami katolickimi - m.in. Związkiem Kobiet Katolickich, Domem św. Rodziny, Radiem Maryja, Caritas Łotwa. Jest członkiem polskiej organizacji ekologicznej REFA.

\section{Authors' notes}

ElgARS FelCIS is a scientist - A scientist at Latvian University and a scientist activist in the field of regenerative transitions. He lives in an Open Homestead "Zadini" and is the president to Latvian Permaculture Association. Interested in deep adaptation, energy transitions and building communities.

WERONIKA FELCIS - Sociologist, evaluator and activist. Secretary in Executive Committee of International Organization for Cooperation in Evaluation. She lives in Latvia from 2016 and cooperated with Holy Family Home in Riga, Radio Maria Latvia, Catholic Women's Association and Caritas Latvia. She is a member of REFA in Poland. 